30. Решительнее бороться с предельщиками и саботажниками // Большевистская смена. 1937. 20 января.

31. Шутов А. Троцкистский выродок // Большевистская смена. 1937. 4 марта.

32. Алексеев В. Троцкистские последыши разоблачены // Большевистская смена. 1937. 6 апреля.

33. Орлов А.В. Срывают маску с врагов // Большевистская смена. 1937. 9 августа.
34. Отвалов Л. Беспощадно разоблачать двурушников // Большевистская смена. 1937. 27 августа.

35. Дорофеева. Приговор суда - приговор народа // Большевистская смена. 1937. 12 сентября.

36. Оренбургская коммуна. 1937. 1 сентября.

37. Центр документации новейшей истории Оренбургской области (далее ЦДНИОО). Ф.969. Оп. 3. Д. 346.

38. ЦДНИОО. Ф. 132 6. Оп. 1. Д. 44. Л. 7.

\title{
A TEST BY THE ARBITRARINESS IN 1937-1938
}

(C) 2018

Fedorova Alla Vladimirovna, doctor of historical sciences, professor of History and Philosophy Department Orenburg State Agrarian University (Orenburg, Russian Federation)

Abstract. Mass political repressions of the 1920s-1950s had serious negative consequences for the life of society and the state. Accurate statistics of political repression in the USSR does not exist, although their scale is extremely large. The author's paper is dedicated to the victims of repression as well as it gives a description of the initiators, participants and executors of the «operation on repression». One of the orders of the NKVD № 00447 of July 30, 1937 contained this word combination. The author considers events related to the repression of 1937-1939 in the Orenburg Region, where the first arrests began in the second half of 1936. The author shows how the established command and administrative system, monstrous judicial arbitrariness, creation of extrajudicial bodies for repressions implementation, the triumph of lawlessness, the state of lawlessness and much more led to mass tragedies. The focus of the researcher is the destruction of the best party and people, industry captains, thousands of honest workers. The author in addition to documents extracted from the Orenburg archives, attracts memories of victims of arbitrariness, as well as materials from personal correspondence with their relatives. The Russian state condemned the long terror and mass persecution of its people as incompatible with the idea of law and justice.

Keywords: command and administrative system; repressive policy; mass repressions; Great Terror; NKVD; Beria; law enforcement and judicial bodies; prosecutor; investigator; Supreme Court of USSR; enemies of people; physical assault methods; fate of repressed; Orenburg Region.

УДК 908(470.43)

Статья поступила в редакцию 10.01.2018

\section{ГЕРОИ СОВЕТСКОГО СОЮЗА - СТУДЕНТЫ КУЙБЫШЕВСКОГО ГОСУДАРСТВЕННОГО ПЕДАГОГИЧЕСКОГО ИНСТИТУТА (ПО МАТЕРИАЛАМ АРХИВА СГСПУ И СОГАСПИ)}

(C) 2018

Храмкова Елена Ленаровна, доктор исторических наук, профессор кафедры отечественной истории и археологии Храмкова Нина Петровна, кандидат исторических наук, профессор кафедры отечественной истории и археологии Самарский государственный соџиально-педагогический университет (2. Самара, Российская Федераџия)

Аннотация. Весной и летом 2017 г. в архиве Самарского государственного социально-педагогического университета были обнаружены личные дела Героев Советского Союза Владимира Михайловича Михеева, Александра Митрофановича Бондарева и Александра Васильевича Новикова. Их имена и подвиги, совершенные в период Великой Отечественной войны, были давно и хорошо известны. Однако благодаря новым документам их удалось впервые связать с педагогическим вузом и историческим факультетом, который они успешно окончили после войны. Установленные факты нашли подтверждение и в документах Самарского областного государственного архива социально-политической истории. 7 ноября 2017 г. на здании СГСПУ (ул. Л. Толстого, 47) установили мемориальную доску с изображениями героев и указанием дат их обучения в педагогическом институте. В ноябре-декабре этого же года в архиве СГСПУ были найдены еще два личных дела - Героев Советского Союза Бориса Михайловича Падалко и Михаила Яковлевича Романова, также окончивших заочное отделение исторического факультета. Обнаруженные материалы вновь были подтверждены материалами СОГАСПИ. Началась работа, направленная на реконструкцию довоенных, военных и послевоенных биографий героев.

В статье впервые на основе личных дел, хранящихся в архиве СГСПУ и СОГАСПИ, рассмотрены известные, малоизвестные и новые факты жизни и деятельности пяти Героев Советского Союза 1941-1945 гг. студентов первых послевоенных наборов Куйбышевского педагогического института. Удалось не только увеличить количество героев, обучавшихся в вузе, но и число Героев Советского Союза Самарской области.

Ключевые слова: Герои Советского Союза; Великая Отечественная война; архив Самарского государственного социально-педагогического университета; Самарский областной государственный архив социально-политической истории; личные дела; Куйбышевский государственный педагогический институт; исторический факультет. 
Еще в 70 х гг. XX века в ходе поисковой деятельности преподавателей и студентов Куйбышевского государственного педагогического института (КГПИ) была реконструирована довоенная и военная биография Петра Михайловича Ганюшина (19191943), уроженца села Горки Сергиевского района нашей области, окончившего факультет русского языка и литературы в 1942 г. 23 декабря 1943 г. командиру взвода 106-го отдельного истребительно противотанкового дивизиона лейтенанту П.М. Ганюшину за подвиг, совершенный в бою за плацдарм на правом берегу Днепра, было присвоено посмертно звание Героя Советского Союза [1, с. 311]. На здании пединститута установлена мемориальная доска, на которой кроме даты гибели указано, что он учился в 1939-1942 гг. Согласно решению Ученого совета ПГСГА (СГСПУ) 25 сентября 2015 г. вузовскому музею истории было присвоено имя Героя Советского Союза П.М. Ганюшина.

В 2017 г. в архиве СГСПУ были обнаружены сохранившиеся личные дела трех Героев Советского Союза, которые в послевоенное время окончили заочное отделение исторического факультета. Это Михеев Владимир Михайлович (24.07.191519.04.1986), Бондарев Александр Митрофанович (30.05.1923-09.07.1996) и Новиков Александр Васильевич (04.12.1924-21.05.1977). 8 ноября этого же года на здании исторического и филологического факультетов (ул. Льва Толстого, д. 47) была установлена мемориальная доска, на которой изображены портреты героев (с фотокарточек из зачетных книжек), содержатся даты присвоения им высокого звания и обучения в КГПИ.

В ноябре-декабре 2017 г. к упомянутым выпускникам истфака добавились еще два Героя Советского Союза - Падалко Борис Михайлович (16.03.192108.04.1986) и Романов Михаил Яковлевич (04.07.1922-12.05.2008). Их личные дела также были найдены в архиве СГСПУ.

Следует подчеркнуть, что материалы личных дел пяти Героев Советского Союза (В.М. Михеев, А.М. Бондарев, А.В. Новиков, Б.М. Падалко, М.Я. Романов) подтверждаются, дополняются, корректируются сведениями, содержащимися в личных делах и других документах, которые хранятся в Самарском государственном архиве социально-политической истории (СОГАСПИ). В настоящее время продолжается их изучение.

Рассмотрим содержание личных дел студентов Героев Советского Союза. Отметим, что информационный потенциал данных источников мало востребован в отечественной исторической науке по причине их недостаточной изученности и доступности; многие из них безвозвратно утрачены. Особенности личных дел студентов советской высшей школы в 2000-е гг. выявлялись несколькими исследователями [2-6]. Их выводы были учтены нами, прежде всего, при определении типо-видовой принадлежности указанных источников. Так, Г.Г. Амалиева рассматривает их как массовый делопроизводственный источник, «обладающий сложной внутренней структурой», источник «официально-личного характера» [2, с. 4, 10, $12,22]$. И с этим трудно не согласиться. Личные дела героев, как и других студентов, формировались со времени подачи ими заявлений на имя директора или заместителя директора по заочному отделению КГПИ и до получения дипломов об окончании вуза. Они включают документы личного и официального происхождения, в том числе обеспечивавшие учебный процесс. Это заявления; автобиографии; анкетные листки; заверенные копии дипломов об окончании двухгодичных партийных школ с приложением выписки из зачетной ведомости; справки с места работы; подлинники аттестатов об окончании общеобразовательных школ; справки о ранении, инвалидности; направления студентов на зачеты и экзамены; вызовы на сессии; рецензии преподавателей на контрольные, курсовые работы; справки о результатах прохождения педагогической практики; учебные карточки студентов заочников; экзаменационные карточки на зимнюю и летнюю сессии; переписка студентов с руководством института; выписки из приказов о допуске к сдаче государственных экзаменов и об окончании исторического факультета; копии дипломов с приложением выписки из зачетных книжек; зачетные книжки и др.

На личных делах упомянутых героев указаны начальная и конечная даты формирования, что позволяет точно определить годы их обучения на заочном отделении исторического факультета. В.М. Михеев и Б.М. Падалко учились на одном курсе в 1948 1950 гг. М.Я. Романов поступил вместе с ними в 1948 г., но завершил обучение в 1953 г. А.М. Бондарев и А.В. Новиков поступали в один год - 1951 г., но первый получил диплом в 1954 г., а второй - в 1956 г. Разные сроки обучения объясняются тем, что после Великой Отечественной войны некоторые будущие студенты историки окончили Куйбышевскую межобластную (областную) партийную школу: В.М. Михеев и Б.М. Падалко в 1948 г. [7, л. 3-3 об.; 8, л. 3-3 об.], А.В. Новиков в 1951 г. [9, л. 17-19]. Приказом Министра высшего образования СССР от 15 августа 1947 г. [10] окончание двухгодичных партийных школ было приравнено к окончанию учительских институтов, поэтому оценки, полученные ими за ряд предметов, были перенесены в зачетки, выданные на истфаке КГПИ.

Нелегко пришлось М.Я. Романову, Б.М. Падалко и В.М. Михееву. Михаил Яковлевич в первый учебный год на историческом факультете учился одновременно в областной партийной школе $[11$, л. $2-$ 2 об.]. Борис Михайлович и Владимир Михайлович в момент поступления в КГПИ летом 1948 г. сдавали государственные экзамены в Куйбышевской областной партшколе [8, л. 3; 12, л. 18-19].

Пожалуй, наиболее последовательно к своему призванию (а он единственный из пяти героев, кто работал всю жизнь учителем истории) шел А.М. Бондарев. В 1948 г. он поступил, а в 1950 г. окончил (заочно) полный курс истфака Бугурусланского государственного учительского института. Ему была присвоена квалификация «учителя истории семилетней школы» [13, л. 21-21 об., 31].

При поступлении в пединститут самому старшему - В.М. Михееву исполнилось 33 года (решение о зачислении в студенты принято в день его рождения - 24 июля), А.М. Бондареву - 28 лет, Б.М. Падалко 27 лет, М.Я. Романову и А.В. Новикову - 26 лет. Это были сформировавшиеся люди с большим жизненным и военным опытом; почти все они во время вой- 
ны неоднократно были ранены. В.М. Михеев являлся инвалидом 2-й группы [7, л. 7]. Б.М. Падалко написал в автобиографии: получил на фронте «7 боевых ранений» [8, л. 2]. А.М. Бондарев за время войны был «три раза ранен и два раза контужен»; в анкетном листке указал 2-ю группу инвалидности [13, л. 2 об., 21 об.]. Тяжелое ранение было у А.В. Новикова, которому пришлось учиться после войны без правой руки. В его личное дело подшита справка, выданная окружным военным госпиталем № 3003 от 13 января 1944 г., об ампутации правой руки. 20 октября 1943 г. Александр Васильевич в боях за Днепровский плацдарм был ранен разрывной пулей [9, л. 6]. О том, насколько ему было тяжело, свидетельствует строчка в автобиографии: «После демобилизации из армии по ранению пришлось много и упорно трудиться, чтобы вновь научиться писать левой рукой» $[9$, л. 2]. К слову сказать, все бумаги А.В. Новикова, заполненные от руки, выполнены четким почерком. В личном деле М.Я. Романова сведений о ранении нет. Однако в автобиографии, хранящейся в личном деле в СОГАСПИ, он написал: «В 1946 году уволен из рядов Советской Армии по состоянию здоровья (запрещены высотные и скоростные полеты)» [14, л. 4 об.].

Конечно, полученные в годы войны ранения иногда становились препятствием для сдачи сессии. Так, в первый год обучения Федору Яковлевичу Водоватову - заместителю директора по заочному отделению [15, с. 129] - пришлось освобождать от зимней сессии А.М. Бондарева по причине его болезни и пребывания в окружном госпитале г. Куйбышева [13, л. 10]. Экзамены и зачеты этой сессии Бондарев сдавал в январе и июле 1952 г., а также летом следующего года [13, л. 36].

В личных делах В.М. Михеева, Б.М. Падалко, М.Я. Романова содержатся сведения об освобождении от платы за обучение, которая составляла для студентов заочного отделения 150 руб. в год [7, л. 6 , $46 ; 8$, л. 22; 11, л. 10]. В качестве причины указано звание Героя Советского Союза. Безусловно, не платили за обучение студенты заочники А.М. Бондарев и А.В. Новиков, несмотря на отсутствие таких данных в их личных делах.

Чтобы составить более полное представление об интересующих нас студентах исторического факультета, необходимо обратиться к их довоенной и военной жизни, дополнив материалы личных дел архива СГСПУ документами СОГАСПИ, а также размещенными в открытом доступе наградными материалами Министерства Обороны РФ.

А.М. Бондарев и А.В. Новиков - наши земляки, родились на территории Куйбышевской (Самарской) области: в селе Николаевка Похвистневского района (Бондарев) и в селе Колодинка Красноярского района (Новиков). В.М. Михеев и М.Я. Романов - соседи: уроженцы села Малые Манадыши Атяшевского района Мордовской АССР (Республика Мордовия) (Михеев) и села Ведянцы Тархановской волости Ардатовского уезда Симбирской губернии (Козловский (Ичалковский) район, Республика Мордовия) (Романов). Б.М. Падалко родился в станице ПриморскоАхтарской Краснодарского края (г. Приморско-Ахтарск) $[13$, л. $2 ; 9$, л. $2 ; 7$, л. 2; 11, л. 2; 8, л. 2].

Все пять будущих героев родились в крестьянских семьях: в автобиографиях А.М. Бондарев,
А.В. Новиков и Б.М. Падалко указали, что родились в «семье крестьянина бедняка», М.Я. Романов - «середняка». 20 июля 1948 г. В.М. Михеев при поступлении в пединститут написал, что он родился в семье крестьянина, а своего отца указал как «проживающего в селе Малые Монадыши» (Михеев писал «Монадыши», а не «Манадыши»). Однако 7 июля этого же года в другой автобиографии, которую он заполнял при утверждении его на должность заведующего военным отделом Дзержинского райкома ВКП (б) г. Куйбышева, Владимир Михайлович не утаил, что в 1930 г. «... в связи с искривлением линии партии по вопросам коллективизации отец мой был раскулачен и сослан в Казахстан, но потом, разобравшись в неправильном раскулачивании, отец мой вернулся из Казахстана в свой дом и работал в колхозе, в который он вступил в селе М. Монадыши Атяшевского района... В 1947 г. отец умер...» [16, л. 4]. Очевидно, именно поэтому Михеев покинул родное село и до 1936 г. работал в Ульяновской и Куйбышевской областях, вернувшись в Малые Манадыши незадолго до призыва на военную службу.

О своих родителях герои пишут крайне скупо. А.М. Бондарев сообщил, что его родители умерли: отец в 1941 г., мать - в 1944 г. У Б.М. Падалко на момент поступления на истфак была жива мама (проживала в станице Приморско-Ахтарской), отец умер в 1945 г. А.В. Новиков потерял мать в 1939 г. Отца В.М. Михеева звали Михаил Иванович, его не стало, как мы уже писали, в 1947 г. Отец М.Я. Романова погиб на фронте в 1942 г.

Также в архиве СГСПУ мало сведений об их собственных семьях (отсутствуют у В.М. Михеева и М.Я. Романова). В анкетном листке А.М. Бондарева, заполненном 17 апреля 1953 г., указано: «Женат. Жена Коновалова Вера Григорьевна, сын Александр». На тот момент он проживал вместе с семьей в с. Борское Куйбышевской области [13, л. 21 об.]. А.В. Новиков был женат, детей не имел. В период учебы на истфаке жил в г. Новокуйбышевске, ул. Кутузова, д. 8, кв. 11 [9, л. 16 об.]. Б.М. Падалко имел жену и двоих детей; студентом истфака проживал в г. Куйбышеве, ул. Вилоновская, д. 2а, кв. 1 [8, л. 2]. Сведения о семейном положении В.М. Михеева и М.Я. Романова удалось выявить в документах СОГАСПИ. Владимир Михайлович был женат на Михеевой Александре Михайловне, их сына звали Владимир. В год поступления в КГПИ они жили вместе с его мамой - Устиньей Михайловной в г. Куйбышеве, ул. Степана Разина, д. 79, кв. 2 [16, л. 3 об.]. Краткие сведения о семье М.Я. Романова мы обнаружили в его личных делах в СОГАСПИ. Жена Михаила Яковлевича работала учителем математики в средней школе № 64 г. Куйбышева. У четы Романовых был сын Александр. Из других близких родственников он указал мать и брата. Семья М.Я. Романова проживала в г. Куйбышеве на улице Чапаевской (сначала в д. 137, кв. 3, затем в д. 200, кв. 4) [14, л. 5; 17, л. 4 об.].

Немаловажным является вопрос об общем и военном образовании будущих студентов исторического факультета Куйбышевского педагогического института. В первом и втором томах биографического справочника «Герои Советского Союза» указывается, что В.М. Михеев окончил начальную школу, 
А.В. Новиков - неполную среднюю школу, А.М. Бондарев и Б.М. Падалко имели среднее образование, М.Я. Романов окончил 9 классов [1, с. $183 ; 18$, с. 97 , 172, 226, 369]. В личных делах СГСПУ содержатся более полные данные. Так, В.М. Михеев в конце 1930-х гг. - 1941 г. окончил двухмесячные курсы во Владивостоке (получил звание младшего политрука); в 1941 г. и дважды в ноябре 1943 г. и ноябре 1944 г. учился на курсах усовершенствования политсостава запаса [7, л. 2]. По объективным причинам (многодетная семья, бедность) не сумел получить среднее школьное образование А.В. Новиков. После окончания начальной школы в родном селе Колодинка он ходил за 15 км в Красноярскую среднюю школу, где окончил 7 классов. Когда ему было 15 лет, умерла его мать. В связи с тяжелым материальным положением он бросил школу и пошел работать. В 1942 г. он окончил 6-месячные курсы при Могилевском пехотном училище. Даже потеря руки на фронте не заставила его оставить надежду на получение образования. В 1947-1948 гг. он начал учиться в 8 классе Куйбышевской областной заочной школы, на «4» и «5» сдал литературу (письменно и устно), историю и биологию, но из-за болезни завершить обучение не смог $[9$, л. 2, 5]. Его мечта о высшем образовании сбудется позже. А.М. Бондарев учился сначала в Николаевской начальной школе, а затем окончил Исаковскую семилетнюю школу (Похвистневский район). В 1939 г. поступил в фельдшерско-акушерскую школу в г. Бугуруслане, которую окончил в 1941 г. $[13$, л. 2]. Б.М. Падалко в 1939 г. окончил 10 классов (средняя школа № 2 г. Краснодар) [8, л. 2]. М.Я. Романов окончил в родном селе Ведянцы неполную среднюю школу, а в 1940 г. - 9 классов Ардатовской средней школы. В 1938-1939 гг. он окончил 1 курс рабфака и аэроклуб в г. Саранске, в 1940-1941 гг. Энгельсскую военную авиационную школу пилотов, в 1941-1943 гг. - Грозненское высшее офицерское летное училище (Грозненское военное авиаучилище летчиков и штурманов). Прославленный летчикштурмовик, желая получить высшее образование, в 24 года вновь садится за школьную парту и в июне 1947 г. получает аттестат зрелости об окончании 10 класса железнодорожной школы № 1 рабочей молодежи (станция Куйбышев). В аттестате 14 предметов: 6 «троек», 6 «четверок» (среди них «литература», «русский язык», «история СССР», «всеобщая история») и 2 «пятерки». Количество «троек» объясняется не столько большим перерывом в школьной учебе, сколько напряженной работой на должности помощника директора по культурно-воспитательной работе ремесленного училища № 6 г. Куйбышева [11, л. 2,12$]$.

В положенный срок будущие герои были призваны на военную службу в Рабоче-крестьянскую Красную Армию. В.М. Михеев в 1937-1940 гг. служил во Владивостоке, однако в документах архива СГСПУ нет ни слова о том, что он «участник боев у озера Хасан в 1938 г.» [18, с. 97]. Краткое упоминание об этом содержится в автобиографии в личном деле Михеева - слушателя Куйбышевской двухгодичной партийной школы [12, л. 4]. Б.М. Падалко в 1939 г. поступил в Таганрогское военное авиационное училище, которое окончил в апреле 1941 г. [19, л. 4]. А.М. Бондарев, М.Я. Романов и А.В. Новиков не бы- ли (по возрасту) призваны в ряды РККА до начала Великой Отечественной войны. Таким образом, В.М. Михеев - единственный, кто получил боевой опыт накануне 1941 г.

Их фронтовая жизнь сложилась по-разному. В стрелковых частях сражались В.М. Михеев, А.В. Новиков и А.М. Бондарев; в штурмовой авиации Б.М. Падалко и М.Я. Романов.

В сентябре 1941 г. в РККА был вновь призван В.М. Михеев, на фронте - с июля 1942 г. Являлся заместителем командира роты, батальона, полка по политчасти в стрелковой дивизии. Свой главный подвиг лейтенант Михеев совершил на завершающем этапе Сталинградской битвы в январе 1943 г. Звание Героя Советского Союза получил 18 мая 1943 г. в возрасте 27 лет [7, л. 2; 18, с. 97]. Материалы личных дел и наградной документации позволили установить перечень других наград Владимира Михайловича: 2 ордена Красного Знамени (1943 г., 1945 г.), орден Красной Звезды (1943 г.), орден Отечественной войны I степени (1985 г.).

А.В. Новикова призвали в июне 1942 г., в действующей армии - с февраля 1943 г. Командир пулеметного отделения сержант Новиков отличился во время битвы за Днепр. Звание Героя Советского Союза присвоено ему 30 октября 1943 г. (почти 21 год). В анкетном листке указал, что кроме этого награжден медалью «За победу над Германией в Великой Отечественной войне 1941-1945 гг.». В 1944 г. демобилизован по ранению [9, л. 2 об., 16; 18, с. 172].

12 октября 1941 г. в РККА добровольцем из г. Бугуруслана ушел А.М. Бондарев. На фронте оказался в том же году. Воевал, как и В.М. Михеев, в стрелковых частях до самого конца войны. Младший лейтенант Бондарев - командир взвода отличился во время битвы за Днепр. Звание Героя Советского Союза ему присвоили 10 января 1944 г. в возрасте 20 лет. Он награжден орденами Александра Невского (1943 г.) и Отечественной войны I степени (1985 г.) [1, с. 183; 13, л. 2-2 об.].

Летчик-штурмовик М.Я. Романов воевал с марта 1944 г. Командир эскадрильи, старший лейтенант Романов к апрелю 1945 г. совершил 110 боевых вылетов. Героем Советского Союза стал в 22 года 29 июня 1945 г. Имел 3 ордена Красного Знамени (1944-1945 гг.), орден Красной Звезды (1944 г.), орден Отечественной войны I степени (1985 г.) [18, с. $369 ; 11$, л. 2-2 об.]. Михаил Яковлевич награжден и медалью «За храбрость перед врагом» («За храбрость против врагов»), учрежденной в декабре 1940 г. правительством Чехословацкой республики. Медаль не фигурирует ни в личном деле в архиве СГСПУ, ни во втором томе биографического словаря «Герои Советского Союза», однако она упоминается в личном листке по учету кадров и автобиографии Романова в СОГАСПИ [14, л. 3 об., 4 об.].

Б.М. Падалко находился в действующей армии с июня 1941 г. Летчик-штурмовик, командир эскадрильи, капитан Падалко к январю 1945 г. совершил 142 боевых вылета, в 23 воздушных боях в составе группы сбил 10 самолетов противника. Звание Героя Советского Союза ему присвоено 18 августа 1945 г. (24 года). Имел 4 ордена Красного Знамени (19431945 гг.), орден Ал. Невского (1945 г.), орден Отечественной войны I степени (1944 г.), 2 медали [18, 
c. $226 ; 8$, л. 2]. В автобиографии, хранящейся в личном деле Падалко в СОГАСПИ, отмечено, что в числе его 10 военных наград есть и медали - «За взятие Кенигсберга», «За победу над Германией в Великой Отечественной войне 1941-1945 гг.» [19, л. 4 об.].

Вот с таким жизненным и военным багажом они пришли учиться в педагогический институт.

Во всех личных делах (кроме А.М. Бондарева) первый лист - это написанное в произвольной форме заявление (прошение), адресованное дирекции КГПИ с просьбой принять на исторический факультет (заочное отделение), поданное в июле месяце в год поступления. На заявлениях В.М. Михеева, Б.М. Падалко, М.Я. Романова и А.В. Новикова есть пометка Ф.Я. Водоватова: принять на 1 курс без вступительных (приемных) экзаменов (испытаний). В данном случае свою роль сыграли имеющиеся льготы для участников войны, Героев Советского Союза при поступлении в вузы.

В деле А.М. Бондарева первый документ - его письмо (от 1 июня 1951 г.) на имя Ф.Я. Водоватова. В нем Александр Митрофанович пишет, что высылает требуемые документы: «две фотокарточки, справку с места работы, автобиографию, копию диплома и копию приложения, подлинник с приложением представлю лично в июле... 1951 года» и интересуется, по какой программе ему досдавать немецкий язык. На письме пометка рукой Водоватова о том, что заявление Бондарева без подлинника диплома разбираться не будет, а немецкий язык сдавать в объеме всей вузовской программы [13, л. 1-1 об.]. В итоге А.М. Бондарев был зачислен сразу на 3 курс после сдачи в июле 1951 г. зачета и экзамена по истории СССР Н.Н. Яковлеву (на «отлично»), зачета по немецкому языку Н.Д. Железнякову, о чем свидетельствуют направления на экзамены и зачеты, а также материалы зачетной книжки [13, л. 6-9, 36].

Материалы личных дел героев (выписки из приказов, направления на зачеты и экзамены, вызовы на сессии студентов заочников, зачетные книжки, копии дипломов с приложением выписки из зачетной книжки и др.) содержат фамилии, оригинальные подписи директоров КГПИ: А.Я. Буровиной и А.Ф. Серова; заместителей директора по заочному отделению Ф.Я. Водоватова, Н. Прокофьева; деканов исторического факультета В.А. Стального и Ф.Ф. Захарова $[15$, с. $129,134-135,154 ; 7$, л. $1,6,47-48,50$, 50 об.; 8 , л. 24,25 об.; 9, л. $1,18,21,58,59$ об.; 11, л. 1,8 об., 9,$11 ; 13$, л. 1, 10, 34-35].

Указанные документы, а также рецензии на контрольные работы позволяют определить исторические, философские, педагогические, психологические, филологические и другие дисциплины, которые осваивали студенты в период обучения на заочном отделении, а также преподавателей данных предметов. Среди них доценты, старшие преподаватели, ассистенты кафедры истории СССР - заведующий кафедрой Н.Н. Яковлев (история СССР, методика преподавания истории), К.Я. Наякшин (история СССР), Ф.Я. Водоватов (спецсеминар по истории СССР), Е.И. Медведев (история СССР), К.В. Левачёва, С.Г. Басин (история СССР, спецсеминар и спецкурс по истории СССР); кафедры всеобщей истории - заведующий кафедрой В.А. Стальный (история нового времени), В.И. Марков (первобытное общество, Древний мир, Древний Восток), Л.А. Ганкин (история средних веков), Д.Н. Кейсер (новая история), С.Б. Лившиц (новая история стран Востока, спецсеминар по новой истории); других факультетов и межфакультетских кафедр - В.Я. Табенецкий, Ф.Ф. Захаров (основы марксизма ленинизма, диамат и истмат); И.М. Киселев (основы советского государства и права); Л.И. Шлёнкина (русская и советская литература), Тейтельбаум (зарубежная литература); Н.Д. Железняков, Штерн (немецкий язык); Порошин, А.С. Щукин (политическая экономия); Н.И. Панков, С.Л. Буевич (история педагогики); А.А. Гайворовский, М.С. Петербургская (психология) и др. [15, с. 7-9, 11-12, $143,145-147,149,153-154,165,167-169]$. К сожалению, у некоторых преподавателей не удалось установить имена и отчества, некоторые фамилии пока не удалось расшифровать.

Сохранились справки о прохождении педагогической практики В.М. Михеевым (средняя школа № 9, г. Куйбышев), Б.М. Падалко (средняя школа, с. Пестравка), А.В. Новиковым (школа семилетка № 1, г. Новокуйбышевск) и М.Я. Романовым (средняя школа № 13, г. Куйбышев). Срок практики был небольшим две недели, в течение которых они давали 4 урока и проводили внеклассные мероприятия. Директора и учителя истории указанных учебных заведений оценили уровень их методической, исторической и педагогической подготовки на «отлично» [7, л. 44; 8, л. 20; 9, л. 49; 11, л. 5]. А.М. Бондарев, скорее всего, на практике не был, так как работал в средней школе им. С.М. Кирова в селе Борское Куйбышевской области $[13$, л. 30]. Ему могли зачесть и педагогическую практику, которую он прошел во время учебы в Бугурусланском учительском институте.

Государственные экзамены все пятеро сдавали по основам марксизма-ленинизма, истории нового времени, истории СССР и педагогике. В.М. Михеев, Б.М. Падалко и А.М. Бондарев сдали все предметы на «отлично». Им была присвоена квалификация и звание учителя средней школы (Бондареву - «учителя 8-10 классов средней школы»). М.Я. Романов получил оценку «хорошо» по основам марксизма-ленинизма и истории СССР; два других госэкзамена сдал на «отлично». Формулировка квалификации и звания в копии его диплома совпадает с В.М. Михеевым и Б.М. Падалко. А.В. Новиков получил по всем предметам «хорошо». В копии его диплома указана специальность - «история» и полученная квалификация - преподаватель средней школы и Конституции.

Как сложилась их жизнь после окончания педагогического института? А.М. Бондарев работал в школе-восьмилетке № 1, средних школах № 2 и № 5, Исаковской средней школе (г. Похвистнево, Похвистневский район) учителем истории, завучем и директором. Был вынужден уехать из г. Похвистнево и в 1970-е гг. обосноваться в г. Тольятти. Здесь он работал преподавателем истории в профессиональнотехническом училище № 30, заместителем директора по учебно-воспитательной работе в техническом училище № 52. Судя по некоторым материалам, именно этот период жизни стал самым тяжелым в жизни Александра Митрофановича. 


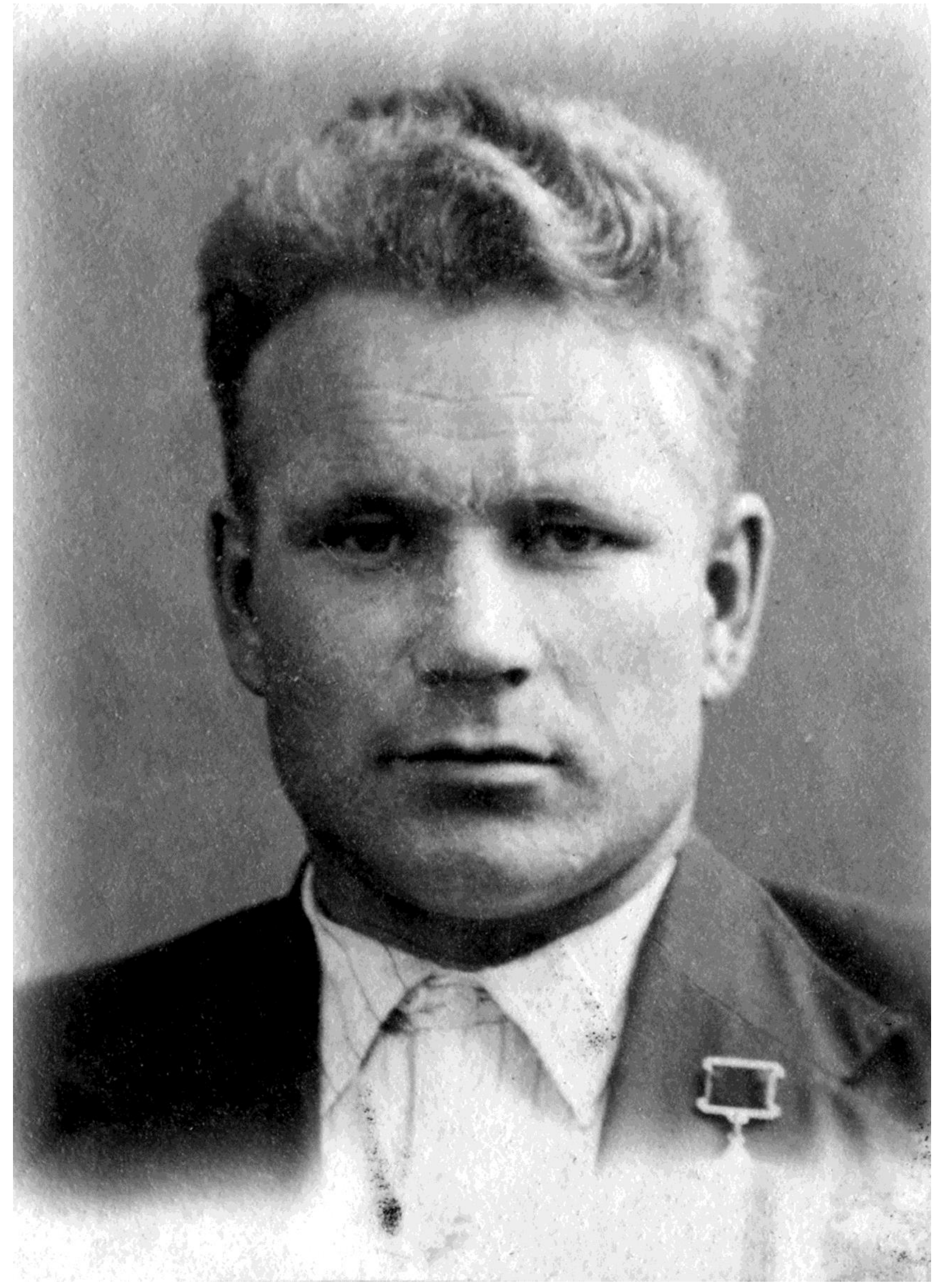

Рисунок 1 - Михеев Владимир Михайлович 


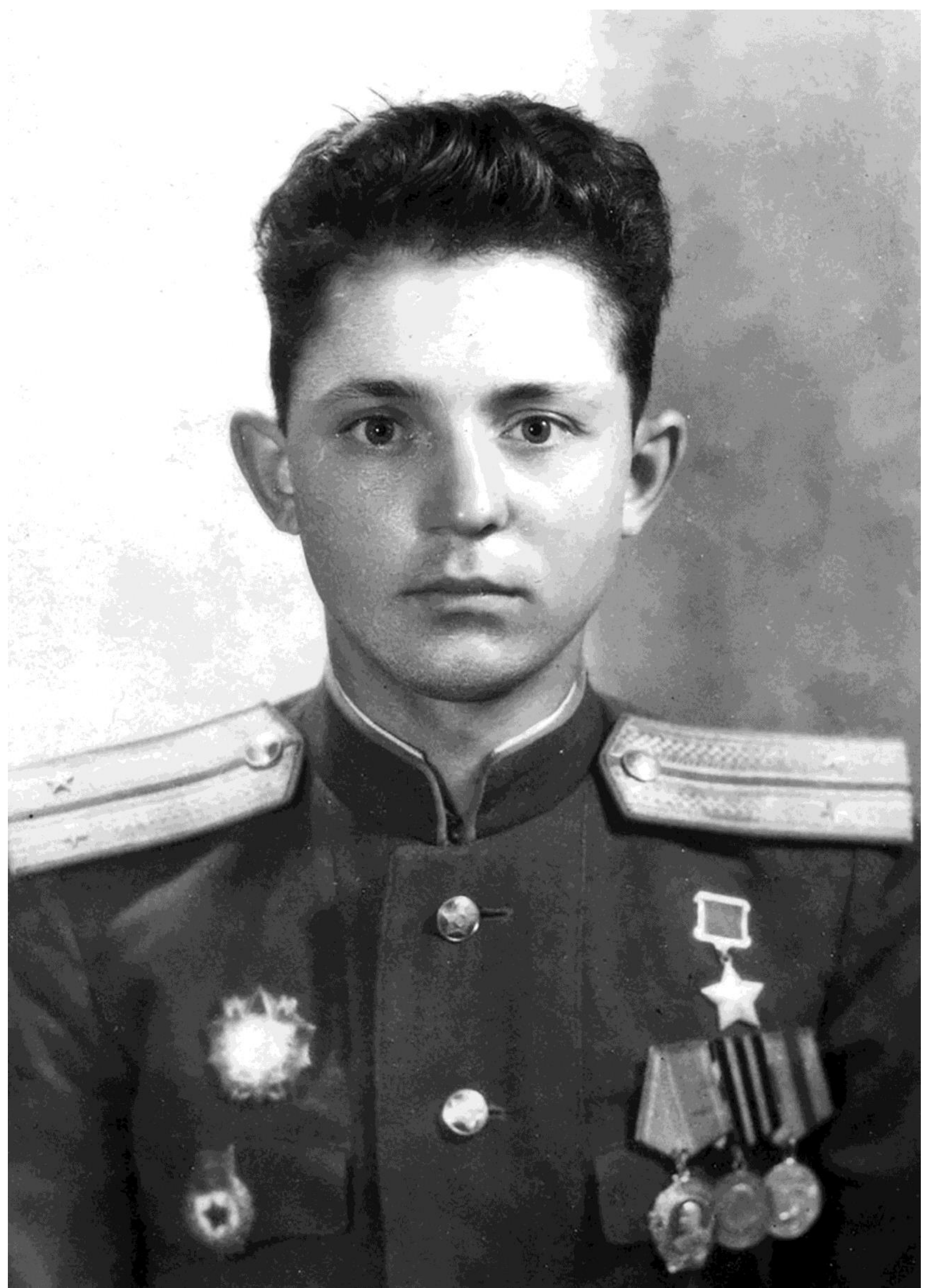

Рисунок 2 - Бондарев Александр Митрофанович 


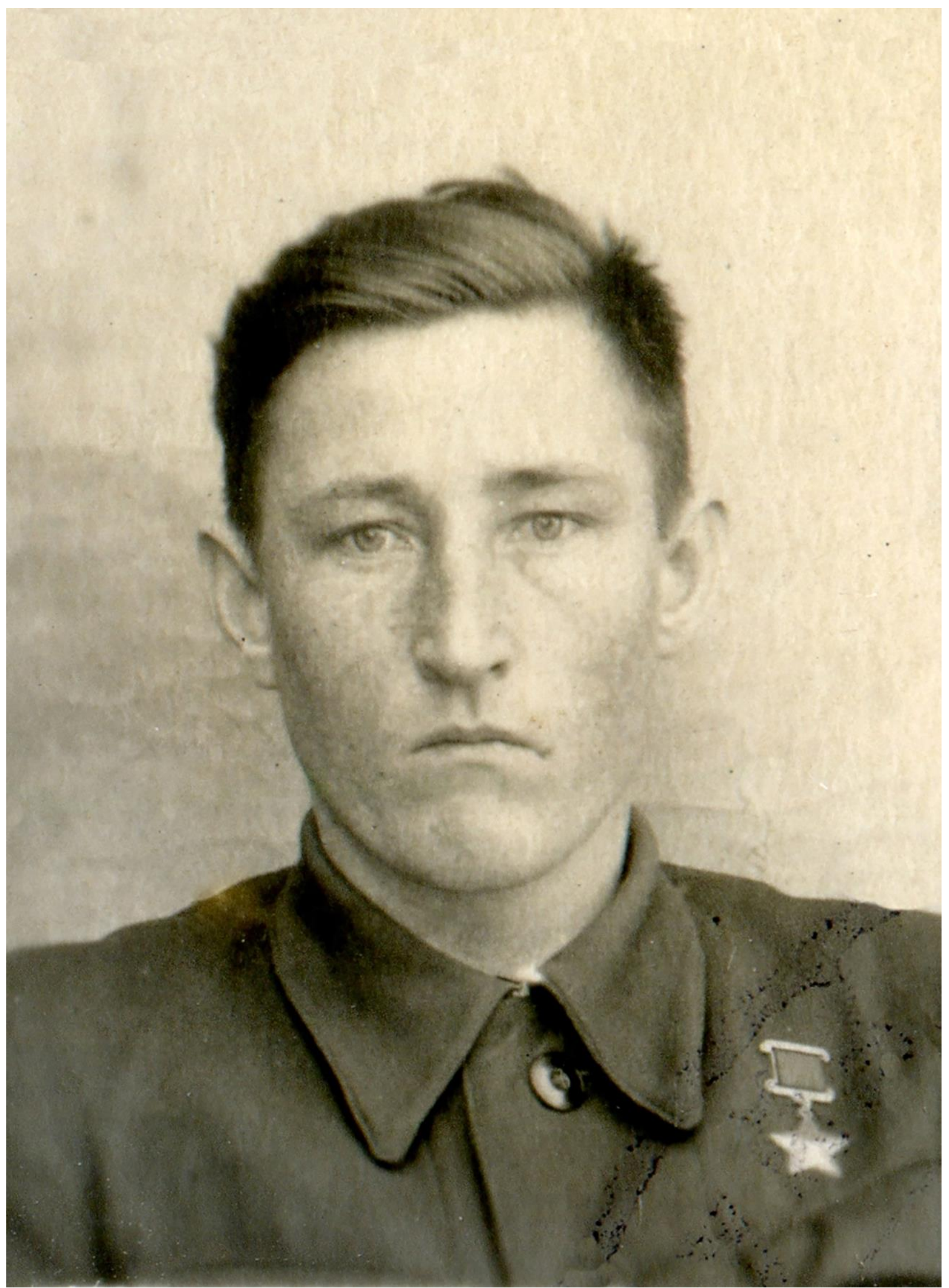

Рисунок 3 - Новиков Александр Васильевич 


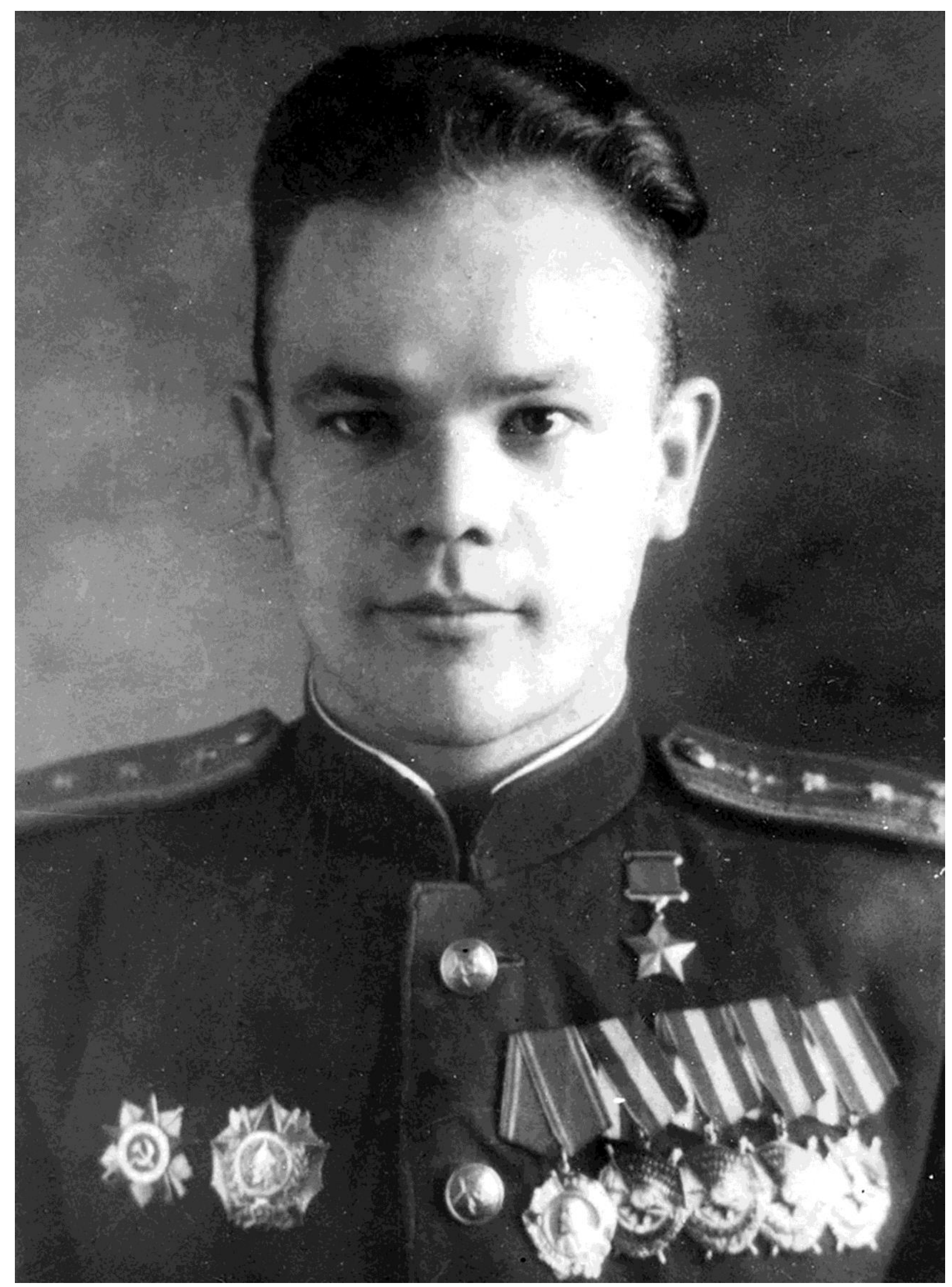

Рисунок 4 - Падалко Борис Михайлович 


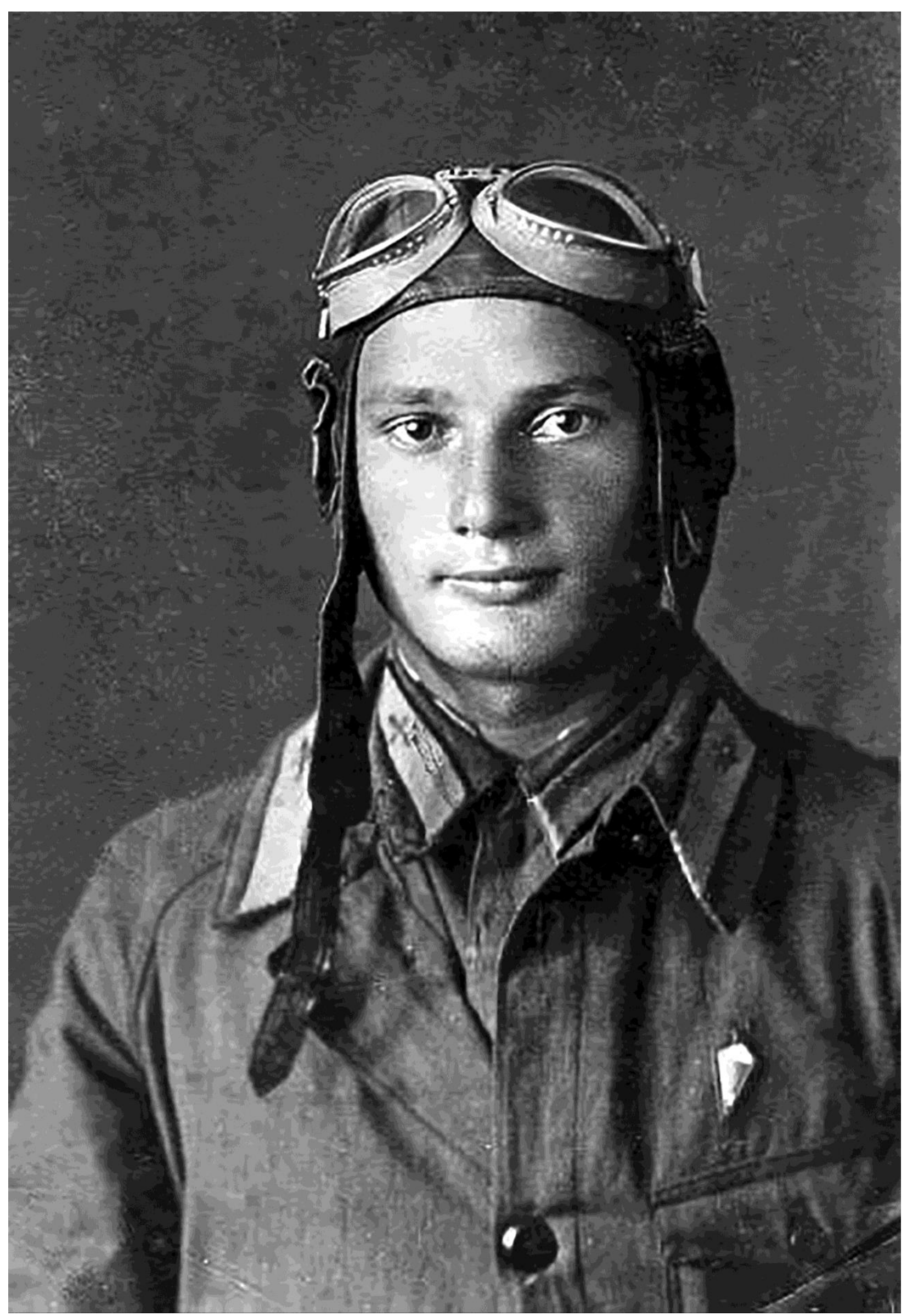

Рисунок 5 - Романов Михаил Яковлевич 
В.М. Михеев исполнял обязанности заведующего военным отделом Дзержинского района г. Куйбышева, с 1958 г. служил в органах МВД: 8 лет работал начальником отряда в колонии усиленного режима, заместителем начальника колонии по политико-воспитательной работе, начальником колонии. В отставку по возрасту ушел в 1975 г. (подполковник внутренней службы).

А.В. Новиков работал на должности секретаря Новокуйбышевского горкома КПСС, в начале 1960-х гг. перешел на хозяйственную работу в Куйбышевский совет народного хозяйства.

Б.М. Падалко работал инструктором отдела партийных, профсоюзных и комсомольских органов Куйбышевского обкома партии, председателем профсоюзного комитета строительной организации «Куйбышевгидрострой», вторым секретарем КинельЧеркасского райкома партии, в Куйбышевском управлении «Главнефтеснаба» РСФСР.

Не совсем обычно сложилась жизнь М.Я. Романова. С начала 1950-х гг. он входил в номенклатуру Куйбышевского обкома КПСС: инструктор административного отдела; инструктор, заместитель заведующего, заведующий отделом административных и торгово-финансовых органов [14]. В 1961 г. перешел на работу в аппарат ЦК КПСС и переехал в Москву. Историческое образование, полученное в КГПИ, пригодилось ему в период работы в Главном архивном управлении СССР в 1969-1991 гг. Реализовал Михаил Яковлевич и свой литературный талант. Любовь к истории родного края, желание сохранить память обо всем пережитом в военные и послевоенные годы нашли отражение в его опубликованных книгах: «Село старинное - Ведянцы», «Мои Родина и Родословная», «Штурмовики над Карпатами» [2023], а также в материалах интервью с ним, опубликованных А.В. Драбкиным [24, с. 276-296]. Остается непонятным, по каким причинам М.Я. Романов «выпал» из всех известных списков Героев Советского Союза Самарской области.

Первым (самым молодым) ушел из жизни Александр Васильевич Новиков - на 53-м году жизни. Похоронен на Городском кладбище г. Самары.

Владимир Михайлович Михеев и Борис Михайлович Падалко скончались в один год и месяц - в апреле 1986 г., в возрасте 70 лет (В.М. Михеев) и 65 лет (Б.М. Падалко). Оба похоронены на кладбище «Рубежное» г. Самары.

В июле 1996 г. в возрасте 73 лет скончался Александр Митрофанович Бондарев, похоронен на Баныкинском кладбище г. Тольятти Самарской области.

Последним в мае в 2008 г. на 84-м году жизни ушел из жизни Михаил Яковлевич Романов. Похоронен на Троекуровском кладбище г. Москвы.

Завершая краткий анализ документов Героев Советского Союза, хранящихся в архиве СГСПУ, и отдельных материалов СОГАСПИ, отметим их значительную информативность, касающуюся не только периода их обучения в Куйбышевском пединституте, но и предвоенной и частично послевоенной биографии. Очень многое об их жизни и деятельности еще предстоит выяснить.

На наш взгляд, главное, что удалось сделать на данном этапе исследования, это документальное обоснование того, что В.М. Михеев, Б.М. Падалко, М.Я. Романов, А.М. Бондарев и А.В. Новиков окончили в конце 1940-х - середине 1950-х гг. историче- ский факультет (заочное отделение) нашего вуза. Немаловажно, что благодаря этому были выявлены документы М.Я. Романова и в СОГАСПИ, что дает возможность включить его в список Героев Советского Союза Самарской области по критериям получения образования и работы в нашем крае.

В настоящее время реконструкция биографий героев продолжается, возможно, что будут получены новые доказательства в отношении, по крайней мере, еще одного Героя Советского Союза Великой Отечественной войны, учившегося в педагогическом институте.

Авторы выражают искреннюю признательность всем, кто помогал им в работе: доктору исторических наук, профессору А.И. Репинецкому, заведующему архивом СГСПУ Т.А. Пениной, сотрудникам СОГАСПИ - кандидату исторических наук, начальнику отдела использования архивных документов Е.М. Малинкину, А.Г. Удинцеву, Л.А. Панкратовой, Д.Н. Моськиной.

\section{Список литературы:}

1. Герои Советского Союза. Краткий биографический словарь / пред. ред. коллегии И.Н. Шкадов. М.: Воениздат, 1987. Т. 1 (Абаев-Любичев). 911 с.

2. Амалиева Г.Г. Личные дела студентов Казанского университета (1917-1925 гг.) как исторический источник: автореф. дис. ... канд. ист. наук: 07.00.09. Казань, 2006. 23 с.

3. Амалиева Г.Г. Электронная коллекция личных дел студентов Казанского университета (19171925 гг.) // Современные информационные технологии и письменное наследие: от древних текстов к электронным библиотекам: мат-лы междунар. конф. (Казань, 26-30 августа 2008 г.). Казань, 2008. С. 13-16.

4. Ягодкина Е.О. Коллективный портрет студентов МГУ послевоенных лет (по материалам личных дел студентов) // Вестник Московского университета. Серия 8: История. 2008. № 3. С. 97-112.

5. Ягодкина Е.О. Студенчество МГУ им. М.В. Ломоносова (1943-1953 гг.): источниковедческое исследование: автореф. дис. ... канд. ист. наук: 07.00.09. М., 2009. 30 c.

6. Слабодцкий В.В., Чернявская Н.К. Личные дела абитуриентов Омского сельскохозяйственного института набора 1918 года как исторический источник // Национальные приоритеты России. Омск, 2015. № 4 (18). С. 14-17.

7. Архив Самарского государственного педагогического университета (СГСПУ). Ф. 2304. Личное дело. Михеев Владимир Михайлович.

8. Архив СГСПУ. Ф. 2304. Личное дело. Падалко Борис Михайлович.

9. Архив СГСПУ. Ф. 2304. Личное дело. Новиков Александр Васильевич.

10. Приказ Минвуза СССР «О дипломах для окончивших партийные школы» от 15.08.1947 № 1177 // Бюллетень Минвуза СССР. 1947. № 9.

11. Архив СГСПУ. Ф. 2304. Личное дело. Романов Михаил Яковлевич.

12. Самарский областной государственный архив социально-политической истории (СОГАСПИ). Ф. 3407. Оп. 5. Д. 128. Михеев Владимир Михайлович.

13. Архив СГСПУ. Ф. 2304. Личное дело. Бондарев Александр Митрофанович.

14. СОГАСПИ. Ф. 656. Оп. 134. Д. 1960. Романов Михаил Яковлевич. 
15. Храмкова Н.П. Исторический факультет Самарского государственного педагогического университета (1929-2005). Самара: СГСПУ, 2009. 324 с.

16. СОГАСПИ. Ф. 656. Оп. 91. Д. 1993. Михеев Владимир Михайлович.

17. СОГАСПИ. Ф. 3407. Оп. 6. Д. 212. Романов Михаил Яковлевич.

18. Герои Советского Союза. Краткий биографический словарь / пред. ред. коллегии И.Н. Шкадов. М.: Воениздат, 1988. Т. 2 (Любов-Ящук). 863 с.

19. СОГАСПИ. Ф. 656. Оп. 134. Д. 1720. Падалко Борис Михайлович.
20. Романов М.Я. Село старинное - Ведянцы. Саранск: Мордовское кн. изд-во, $1992.91 \mathrm{c}$.

21. Романов М.Я. Мои Родина и Родословная: беседа автора с читателем. М., 2006. 216 с.

22. Романов М.Я. Штурмовики над Карпатами: воспоминания о Великой Отечественной войне (1941-1945). М.: Дельта НБ, 2006. 263 с.

23. Татиевская Л.Е. Рецензия - Романов М.Я. Мои Родина и Родословная: беседа автора с читателем. М., 2006. 220 с. // Отечественные архивы. 2008. № 1. C. $110-111$.

24. Драбкин А.В. Я дрался на Ил-2. М.: Яуза, Эксмо, 2008. 416 с.

\title{
HEROES OF THE SOVIET UNION - STUDENTS OF KUIBYSHEV STATE PEDAGOGICAL INSTITUTE (BASED ON THE ARCHIVE OF SAMARA STATE UNIVERSITY OF SOCIAL SCIENCES AND EDUCATION AND SAMARA STATE ARCHIVE OF SOCIAL AND POLITICAL HISTORY)
} (C) 2018

\author{
Khramkova Elena Lenarovna, doctor of historical sciences, \\ professor of Domestic History and Archeology Department \\ Khramkova Nina Petrovna, candidate of historical sciences, \\ professor of Domestic History and Archeology Department \\ Samara State University of Social Sciences and Education (Samara, Russian Federation)
}

\begin{abstract}
In the spring and summer of 2017 personal files of the Soviet Union Heroes Vladimir Mikhaylovich Mikheyev, Alexander Mitrofanovich Bondarev and Alexander Vasilyevich Novikov were found in archives of Samara State University of Social Sciences and Education (SSUSSE). Their names and feats made during the Great Patriotic War were known. However thanks to the found documents the authors managed to connect them with the pedagogical university for the first time. Established facts were supported by the documents of Samara State Archive of Social and Political History (SSASPH). On November 7, 2017 the memorial plate with images of heroes and dates of their training at the pedagogical university were created and placed on the university building (L. Tolstoy St., 47). In November-December of the same year personal records of two more Soviet Union Heroes - Boris Mikhaylovich Padalko and Mikhail Yakovlevich Romanov were found in archive of SSUSSE. They also graduated from Kuibyshev pedagogical university after the war. The received materials have been confirmed with the materials of SSASPH again. The paper considers new facts of life and activity of five Soviet Union Heroes of 1941-1945 on the basis of personal records which are stored in archives of SSUSSE and SSASPH. The number of the heroes who graduated from Samara State University of Social Sciences and Education as well as the number of the Soviet Union Heroes of the Samara Region has successfully increased.

Keywords: Soviet Union Heroes; Great Patriotic War; archive of Samara State University of Social Sciences and Education; Samara Regional State Archive of Social and Political History; personal files; Kuibyshev State Pedagogical Institute; history department.
\end{abstract}

УДК 94(595)

Статья поступила в редакцию 11.12.2017

\section{«БРИТАНСКИЙ ПУТЬ» КОНТРПАРТИЗАНСКОЙ БОРЬБЫ: РЭНД, ДЕКОЛОНИЗАЦИЯ И ПОЛИТИКА ЧРЕЗВЫЧАЙНОГО ПОЛОЖЕНИЯ В МАЛАЙЕ (1948-1960 ГОДЫ)}

(C) 2018

Лёзин Александр Иванович, студент исторического факультета

Нестеров Дмитрий Александрович, магистрант кафедры всеобщей истории, права и методики обучения Самарский государственный социально-педагогический университет (2. Самара, Российская Федераџия)

Аннотация. В статье рассматривается политика чрезвычайного положения, проводимая британцами в Малайе. Исследование вопроса основывается на аналитических работах сотрудников американской корпорации РЭНД. Малайский конфликт считается примером успешной организации контрпартизанской борьбы в эпоху деколонизации в странах третьего мира. Именно поэтому этот конфликт тщательно изучался корпорацией РЭНД как эталон борьбы с повстанцами, что подтверждает интерес США к анализу и методам борьбы с повстанческим движением до Вьетнамской войны. РЭНД работала на правительство США, то есть министерство обороны подписывало контракты с данной корпорацией. США попробуют на практике применить во Вьетнаме определенные методы борьбы с партизанами, опробованные в Малайе, но стоит учесть, что каждый конфликт индивидуален. В статье показана эволюция коммунистического движения в Малайе - от его зарождения до победы британцев и постепенной победы над повстанческим движением. Конфликт являлся выгодным для Великобритании, поскольку основное население Малайи не было заинтересовано в уходе британцев, местная элита поддерживала британскую корону. Статья демонстрирует особенности малайского конфликта. 